\title{
Alat Pemantau Jumlah Hasil Produksi dalam Industri Sepatu
}

\author{
Nikolas Tjandra ${ }^{1}$, Hugeng Hugeng ${ }^{1}$, Nurwijayanti ${ }^{2}$
}

\begin{abstract}
The development of the footwear industry is growing rapidly in the current modern world. The process of monitoring the amount of production is a major concern for all industries in the world. The monitoring system is mostly manual so that the production process has not been automated. This factor would cause difficulties for the production process to achieve production targets. The design of the monitor of the amount of production in the footwear industry will use an infrared sensor as a detector of number of shoes produced, then data from the sensor are transmitted wirelessly and received by the PC via the LAN connection. The advantages gained from the designed device is that the system is already automated, so it does not require manual counting of the number of shoes production and reduces human error. The device is equipped with a buzzer that serves as a marker that the failure is more than a specified percentage in each line of production. Warning on a PC with a display will appear red on the production line so that the head of the production can immediately handle the problem. The device is also designed to display the output data online with remote desktop technology so that the production process can be monitored by the company from anywhere throughout an Internet connection.
\end{abstract}

Keywords: automated footwear industry, automated monitoring, wireless, LAN, online, internet

\begin{abstract}
ABSTRAK: Perkembangan dunia industri sepatu sudah semakin berkembang pesat dan mengikuti perkembangan zaman yang ada. Proses pemantauan jumlah hasil produksi menjadi perhatian utama bagi semua industri yang ada di dunia. Sistem monitoring pada umumnya masih bersifat manual sehingga proses produksi belum terotomatisasi. Hal ini tentunya akan menghambat jalannya proses produksi sehingga target produksi sulit untuk dicapai. Perancangan dan implementasi alat pemantau jumlah hasil produksi dalam industri sepatu ini akan menggunakan sensor inframerah sebagai pendeteksi sepatu, yang kemudian data hasil sensor dikirimkan secara wireless dan diterima oleh personal computer (PC) melalui LAN. Keuntungan yang dapat diperoleh dari perancangan alat ini adalah sistem sudah bersifat otomatis sehingga tidak memerlukan penghitungan jumlah produksi secara manual dan mengurangi kesalahan manusia. Alat pemantau hasil produksi sepatu ini dilengkapi dengan buzzer yang berfungsi sebagai penanda bahwa sedang terjadi kegagalan yang melebihi dari persentase yang ditentukan di setiap line produksi. Peringatan pada PC pun akan muncul dengan tampilan berwarna merah pada line produksi yang bermasalah sehingga kepala produksi dapat segera menangani masalah yang ada. Alat ini juga dirancang agar dapat menampilkan data-data hasil produksi secara online dengan teknologi desktop remote sehingga proses produksi dapat dipantau oleh pimpinan perusahaan dari mana saja melalui koneksi internet.
\end{abstract}

Kata kunci: industri sepatu, monitoring, wireless, LAN, online, internet

\section{PENDAHULUAN}

$\mathrm{P}$ roses produksi dalam dunia industri memegang peranan yang sangat penting demi berlangsungnya suatu industri. Produksi adalah kegiatan untuk menciptakan atau menambah kegunaan suatu barang atau jasa dengan menggunakan faktor-faktor yang ada seperti tenaga kerja, mesin, bahan baku dan dana agar lebih bermanfaat bagi kebutuhan manusia. Kelancaran proses produksi sangat diutamakan dalam suatu industri agar dapat diperoleh hasil yang maksimal sehingga tidak menimbulkan kerugian. Banyak faktor yang sangat berperan dalam memperoleh kualitas dan kuantitas produksi yang baik, dimana yang menjadi faktor utamanya adalah sumber daya manusia, sumber daya alam, dan sumber daya keuangan yang baik. Suatu proses produksi terdiri dari berbagai macam tahapan dimulai dari tahap awal sampai tahap akhir produksi. Pada proses produksi biasanya terdapat suatu tahapan yang dinamakan quality control (QC). Quality Control adalah sistem kegiatan yang secara teknis rutin dilakukan untuk mengukur dan mengontrol kualitas hasil produksi. Pada tahap ini semua hasil produksi akan diperiksa ulang untuk dipisahkan antara hasil yang sudah layak dijual dan hasil yang gagal.

Proses produksi pada industri sepatu merupakan bagian yang paling diutamakan. Bagian produksi dalam industri sepatu dibagi - bagi menjadi beberapa tahapan produksi di antaranya mulai dari cutting process, Stitching/Sewing Process, Stockfit Process, Assembling Process, dan Finishing. Proses pemantauan jumlah hasil produksi di industri sepatu umumnya pada saat ini masih dilakukan secara manual yaitu dengan cara melakukan pemantauan langsung ke lapangan secara rutin pada waktu tertentu. Hal lain yang menjadi permasalahan dalam suatu industri adalah ketidakjujuran pekerja dalam melakukan penghitungan hasil produksi. Sebagai contoh, jika pimpinan industri sedang tidak berada di tempat, maka pemilik industri akan kesulitan untuk memantau hasil produksi. Pemilik industri harus bertanya kepada bagian divisi produksi untuk menanyakan apakah hasil produksi sudah mencapai target yang ditentukan atau belum. Bagian divisi produksi bisa memanipulasi data jumlah produksi yang diperoleh kepada pemilik perusahaan mengenai jumlah hasil produksi sudah memenuhi target atau belum, sehingga pimpinan industri bisa salah dalam mengambil keputusan ketika pimpinan industri sedang tidak berada di tempat.

Berdasarkan dari fakta yang ada, maka dirancang suatu alat elektronik dimana alat tersebut dapat menghitung secara otomatis jumlah produksi sepatu yang telah lolos dari tahap quality control sehingga dapat dihitung jumlah barang yang sukses dan jumlah barang yang gagal dari hasil produksi. Alat ini juga bisa digunakan

\footnotetext{
${ }^{1}$ Program Studi Teknik Elektro, Fakultas Teknik, Universitas Tarumanagara

2 Jurusan Teknik Elektro, Universitas Suryadarma
} 
untuk meningkatkan hasil produksi dengan sistem kompetisi. Sistem kompetisi yang dimaksud adalah kompetisi antar pekerja dari semua line produksi. Pekerja-pekerja dari setiap line produksi akan berusaha bekerja

lebih cepat untuk mecapai target yang telah ditentukan dan yang berhasil mencapai target terlebih dahulu maka pekerja-pekerja di line tersebut akan mendapatkan upah lebih. Alat elektronik ini digunakan untuk memantau jumlah hasil produksi dalam industri dan bisa diakses langsung melalui jaringan internet sehingga pemilik industri bisa memantau langsung proses produksi setiap harinya walaupun sedang tidak berada di industri tanpa perlu bertanya kepada bagian divisi produksi.

Survei yang dilakukan dalam perancangan alat ini adalah dengan cara survei lapangan, yaitu dengan peninjauan langsung. Survei dilakukan dengan melakukan peninjauan langsung di kedua tempat, yaitu pabrik dari sepatu Eagle yang berada di daerah Balaraja dan PT Unimitra Kharisma sebagai pabrik dari sepatu Pierro yang berada di Jalan Raya Cileungsi Km 17. Survei di pabrik dari sepatu Eagle dilaksanakan pada tanggal 21 November 2012 dan survei pada pabrik dari PT. Unimitra Kharisma dilaksanakan pada tanggal 27 November 2012. Pada survei ini, ada beberapa hal yang menjadi perhatian utama dalam pembuatan alat pemantau hasil produksi ini yaitu pengambilan data jumlah hasil produksi sepatu, pengiriman data jumlah hasil produksi sepatu, sistem produksi sepatu, jaringan yang digunakan untuk memantau produksi, pengawasan kegagalan dalam produksi sepatu.

Proses survei pada kedua pabrik sepatu ini dilakukan berdasarkan urutan dari tahap-tahap memproduksi sepatu mulai dari bahan baku hingga menjadi sepatu yang akan dijual ke pasaran. Tahap pertama adalah tahap Cutting Process yang merupakan tahap pemotongan bahan baku yang akan dibentuk menjadi bagian upper shoes (bagian atas sepatu). Tahap kedua adalah tahap Sewing Process yang merupakan tahap penjahitan bahan baku yang telah dipotong untuk dibentuk menjadi bagian upper shoes. Tahap ketiga adalah tahap Stockfit Process yang merupakan tahap menggabungkan bagian bottom shoes (bagian bawah sepatu) yang terdiri dari midsole dan outsole. Tahap keempat adalah tahap Assambeling Process yang merupakan tahap menggabungkan bagian bawah dan bagian atas sepatu sehingga menjadi sepatu yang utuh. Tahap kelima adalah tahap finishing merupakan tahap terakhir dari proses produksi sepatu dan akan melewati pemeriksaan kualitas apakah sepatu tersebut layak dijual atau tidak sebelum masuk ke bagian packaging.

Survei dipusatkan pada tahap finishing pada setiap line produksi sepatu yang ada di kedua pabrik sepatu tersebut. Pada tahap finishing biasanya akan dilakukan penghitungan jumlah sepatu yang telah melewati bagian pemeriksaan kualitas yang menentukan apakah sepatu tersebut layak dijual atau tidak. Penghitungan sepatu ini masih secara manual sehingga setelah itu data hasil penghitungan harus dikirimkan terlebih dahulu ke bagian kepala produksi. Data yang telah diperoleh oleh kepala produksi akan diberikan kepada pimpinan perusahaan. Proses pengiriman data hasil penghitungan masih menggunakan cara manual sehingga belum ada otomatisasi yang bekerja pada kedua pabrik ini.

- Tabel 1. Perbandingan hasil survei dengan alat yang dirancang Hasil Survei

Pabrik Sepatu Eagle

Pengambilan data jumlah

hasil produksi secara manual

Pengiriman data jumlah hasil produksi dilakukan oleh pekerja

Sistem produksi masih secara manual sehingga sulit untuk meningkatkan hasil produksi

Tidak menggunakan jaringan LAN untuk memantau hasil produksi

Tidak ada penunjuk kegagalan dari setiap line produksi
Pabrik Sepatu Pierro

Pengambilan data jumlah

hasil produksi secara manual

Pengiriman data jumlah hasil produksi dilakukan oleh pekerja

Sistem produksi masih secara manual sehingga sulit untuk meningkatkan hasil produksi

Tidak menggunakan jaringan LAN untuk memantau hasil produksi

Ada pekerja yang bertugas mengawasi kegagalan dari setiap line produksi
Alat yang dirancang

Pengambilan data jumlah hasil produksi secara otomatis dengan menggunakan sensor

Menggunakan modem internet untuk sistem pengiriman data

Sistem produksi dapat menggunakan sistem kompetisi untuk meningkatkan hasil produksi dengan adanya tampilan LCD

Menggunakan jaringan LAN untuk memantau hasil produksi

Menggunakan buzzer apabila jumlah kegagalan lebih dari yang diinginkan dari setiap line produksi 
Berdasarkan latar belakang dan survei di atas, maka dirancang suatu alat elektronik yang berfungsi untuk memantau jumlah hasil produksi dalam industri secara otomatis dan bisa diakses langsung melalui jaringan internet sehingga pimpinan industri bisa memantau langsung proses produksi setiap harinya walaupun sedang tidak berada di industri. Sensor yang digunakan untuk menghitung data adalah sensor inframerah yang akan terpasang di setiap line produksi. Sensor inframerah ini akan dipasang untuk menghitung jumlah produksi yang berhasil dan hasil produksi yang gagal. Data jumlah hasil produksi yang telah diperoleh dari hasil sensor akan dikirimkan secara wireless dari mikrokontroler setiap line ke mikrokontroler pusat dan diteruskan melalui suatu modul Transmission Control Protocol / Internet Protocol (TCP/IP) ke PC yang berada di ruangan kepala produksi.

Data hasil sensor nantinya juga akan ditampilkan ke suatu LCD dimana buruh-buruh pabrik yang sedang bekerja dapat melihat sudah seberapa jauh kerja mereka dari target yang telah ditentukan oleh kepala produksi. Alat ini juga dilengkapi dengan fitur buzzer yang berfungsi ketika persentase gagal lebih dari yang sudah ditentukan oleh kepala produksi maka buzzer yang terpasang di alat ini akan berbunyi dan juga akan mengeluarkan warning di PC kepala produksi, sehingga kepala produksi dapat langsung melakukan pemantauan ke lapangan untuk memeriksa ada permasalahan apa yang terjadi di line produksi. Alat ini juga dilengkapi suatu fitur di mana kepala produksi dapat mengirimkan pesan berjalan ke LCD yang dipasang di tempat buruh bekerja. Karena biasanya untuk menyampaikan informasi kepada buruh-buruh yang sedang bekerja tidak mungkin dilakukan secara manual, mengingat tingginya intensitas suara (kebisingan) mesin - mesin di suatu industri. Fitur selanjutnya adalah suatu fitur laporan yang berguna untuk menyimpan data-data hasil produksi sepatu sehingga dapat dilakukan perbandingan hasil produksi secara harian, mingguan, bulanan, maupun tahunan.

Tujuan perancangan sistem ini adalah untuk membuat suatu alat elektronik yang dapat melakukan pemantauan jumlah hasil produksi secara otomatis dan jumlah hasil produksi dapat dipantau secara online melalui aplikasi remote desktop dari PC maupun tablet PC.

\section{KONSEP SISTEM}

Alat yang dirancang dalam penelitian ini adalah alat pemantau jumlah hasil produksi dalam industri sepatu. Alat ini berfungsi untuk memantau jumlah hasil produksi sepatu yang berhasil dan yang gagal secara otomatis. Data hasil produksi yang sudah diperoleh juga dapat dipantau langsung secara online oleh pimpinan industri melalui koneksi internet, sehingga pimpinan industri dapat memantau terus data jumlah produksi yang sedang berjalan walaupun sedang berada di luar industri. Hal ini dikarenakan pimpinan industri bisa saja sedang berada di tempat yang jauh dari lokasi industrinya baik yang sedang berada di area lokal maupun sedang berada di luar negeri.

Perancangan alat elektronik ini terdiri atas beberapa modul/subsistem yaitu modul mikrokontroler yang berguna untuk mengatur jalannya proses-proses dari pengolahan data, modul sensor yang digunakan untuk menghitung jumlah produksi sepatu baik yang berhasil maupun yang gagal, modul buzzer yang berguna untuk memberikan warning atau peringatan jika persentase kegagalan lebih dari yang ditentukan, modul transceiver berguna dalam proses pengiriman data secara wireless yang terhubung dengan mikrokontroler, modul TCP/IP berguna dalam pengiriman data hasil produksi dari modul transceiver yang kemudian akan diteruskan ke komputer.

Alat ini bekerja dengan menggunakan modul sensor inframerah untuk dapat menghitung jumlah produksi sepatu dari suatu line produksi. Sensor inframerah ini berfungsi menghitung jumlah sepatu yang berhasil dan yang gagal. Penentuan sepatu antara yang berhasil dan yang gagal ditentukan oleh pekerja yang berada di setiap line produksi. Sensor untuk menghitung sepatu yang berhasil diletakkan terpisah dengan sensor untuk menghitung sepatu yang gagal di setiap line produksi.

Data yang telah diperoleh dari sensor disimpan ke dalam mikrokontroler setiap line produksi dan kemudian dikirimkan ke mikrokontroler pusat secara wireless. Proses pengiriman data dari mikrokontroler yang ada di setiap line ke mikrokontroler pusat menggunakan metode handshaking. Data yang tersimpan di mikrokontroler pusat diteruskan ke suatu modul TCP/IP yang kemudian diteruskan sampai ke PC yang berada di ruangan kepala produksi. Data hasil sensor juga ditampilkan ke suatu LCD monitor di mana pekerja-pekerja pabrik yang sedang bekerja dapat melihat apakah hasil produksi sudah mencapai target yang telah ditentukan oleh kepala produksi atau belum.

Alat pemantau jumlah hasil produksi sepatu ini dilengkapi dengan fitur buzzer atau alarm yang terpasang di setiap line produksi. Buzzer ini menyala jika persentase kegagalan melebihi dari batas yang ditentukan. Fitur ini juga memberikan warning atau peringatan di komputer kepala produksi jika terjadi kegagalan yang melebihi dari batas yang sudah ditentukan sehingga kepala produksi dapat langsung melakukan pemantauan pada line produksi yang bermasalah. Alat ini juga dilengkapi dengan fitur pesan berjalan yang ditampilkan pada LCD monitor. Fitur ini bertujuan untuk menyampaikan informasi dari kepala produksi kepada pekerja-pekerja yang sedang bekerja. Hal ini dikarenakan mengingat bisingnya intensitas suara mesin-mesin industri yang sedang bekerja sehingga sulit untuk menyampaikan informasi kalau harus dilakukan secara manual. Fitur selanjutnya adalah suatu fitur laporan yang berguna untuk melihat hasil produksi secara harian, mingguan, bulanan, maupun tahunan sehingga dapat dilihat perbandingan hasil produksi sepatu dari waktu ke waktu. 


\section{Diagram Blok}

Berdasarkan deskripsi konsep yang telah dijelaskan, maka dapat dibuat sebuah diagram blok yang mewakili cara kerja alat yang dapat dilihat pada Gambar 1. Diagram blok ini akan menjelaskan bagaimana sistem keseluruhan dari alat pemantau hasil produksi sepatu ini bekerja.

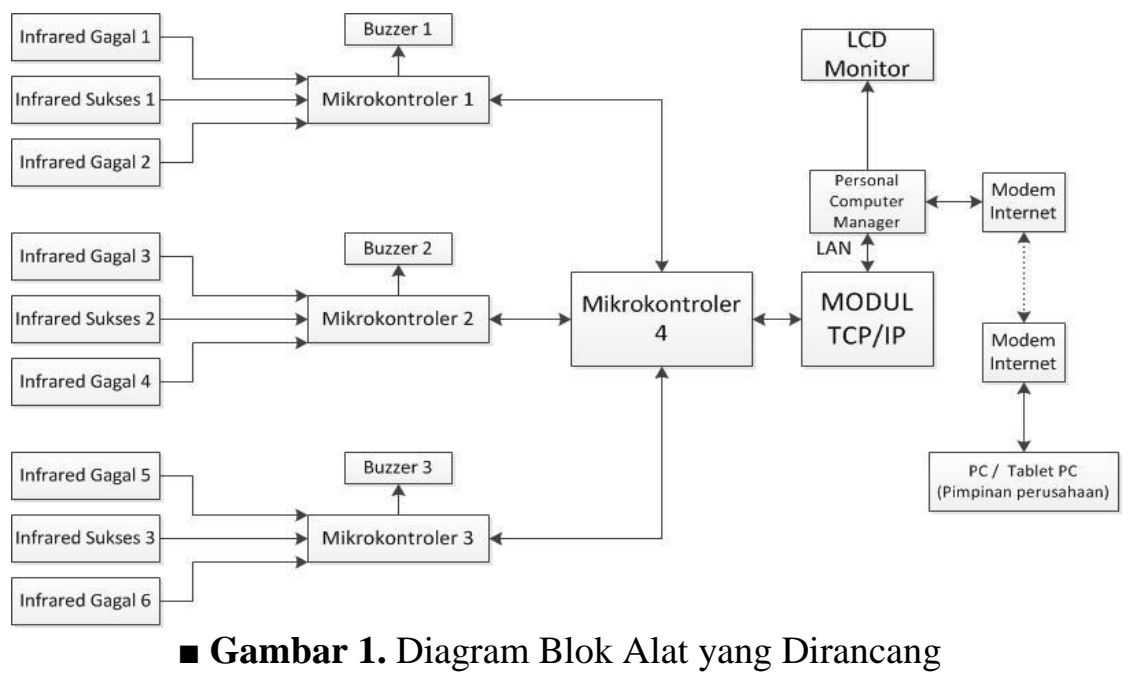

KOMUNIKASI SERIAL

Komunikasi serial merupakan komunikasi data dengan pengiriman data secara satu per satu (per bit) dengan menggunakan satu jalur kabel data. Komunikasi serial hanya menggunakan 2 kabel data yaitu kabel data untuk pengiriman yang disebut transmitter dan kabel data untuk penerimaan yang disebut receiver. Kelebihan dari komunikasi serial adalah jarak pengiriman dan penerimaan dapat dilakukan dalam jarak yang cukup jauh dibandingkan dengan komunikasi secara paralel. Tetapi kekurangannya adalah kecepatan yang lebih lambat bila dibandingkan komunikasi paralel. Beberapa contoh komunikasi serial adalah mouse, scanner dan sistem akuisisi data yang terhubung ke port COM1 / COM2. Pada prinsipnya, komunikasi serial adalah komunikasi dimana transmisi data dilakukan per bit. Interface serial hanya membutuhkan jalur yang sedikit (umumnya hanya 2 jalur), sehingga lebih menghemat pin jika dibandingkan dengan interface paralel.

Komunikasi serial ada 2 macam, asynchronous serial dan synchronous serial. Synchronous serial adalah komunikasi dimana hanya ada satu pihak (pengirim dan penerima) yang menghasilkan clock dan mengirimkan clock tersebut bersama-sama dengan data. Contoh penggunaan synchronous serial terdapat pada transmisi data keyboard. Asynchronous serial adalah komunikasi dimana kedua pihak (pengirim dan penerima) masing-masing menghasilkan clock namun hanya data yang ditransmisikan, tanpa clock. Agar data yang dikirim sama dengan data yang diterima, maka kedua frekuensi clock harus sama dan harus terdapat sinkronisasi. Setelah ada sinkronisasi, pengirim akan mengirimkan datanya sesuai dengan frekuensi clock penerima.

Komunikasi serial ini pada dasarnya yang dikirimkan adalah tegangan yang kemudian dibaca dalam format bit. Besar level tegangannya berkisar antara -25 Volt sampai dengan +25 Volt. Bit dengan logika 1 memiliki level tegangan antara -3 Volt sampai -25 Volt. Bit dengan logika 0 memiliki besar level tegangan antara +3 Volt sampai +25 Volt, sehingga masalah cable loss bukanlah masalah besar pada komunikasi serial. Komunikasi paralel dapat mentransmisikan beberapa bit dalam satu periode. Keunggulan komunikasi paralel ini dibandingkan dengan komunikasi serial adalah pada frekuensi yang sama, komunikasi data dengan komunikasi paralel memiliki kecepatan yang lebih tinggi dibandingkan dengan komunikasi serial. Transfer data yang dilakukan secara bersamaan dalam satu periode waktu, serta ketersediaan port input yang banyak, membuat komunikasi paralel tidak membutuhkan rangkaian perangkat keras tambahan yang rumit.

\section{MIKROKONTROLER}

Mikrokontroler adalah sebuah chip yang berfungsi sebagai pengontrol rangkaian elektronik dan umunya dapat menyimpan program di dalamnya. Mikrokontroler umumnya terdiri dari CPU (Central Processing Unit), memori, I/O tertentu dan unit pendukung seperti Analog-to-Digital Converter (ADC) yang sudah terintegrasi di dalamnya. Mikrokontroler sendiri diprogram dengan perangkat lunak, yang di antaranya menggunakan bahasa pemrograman C. Format bahasa pemrograman $\mathrm{C}$ akan secara otomatis diubah menjadi bahasa assembler dengan format hexadecimal. Perangkat lunak pada mikrokontroler dapat dibagi menjadi lima kelompok sebagai berikut: Instruksi Transfer Data, Instruksi Aritmatika, Instruksi Logika dan Manipulasi Bit, Instruksi Percabangan, Instruksi Stack, I/O, dan kontrol. 


\section{SENSOR INFRAMERAH}

Cahaya inframerah merupakan cahaya yang tidak tampak. Cahaya inframerah memiliki panjang gelombang antara $700 \mathrm{~nm}$ sampai $1 \mathrm{~mm}$ dan berada pada spektrum berwarna merah [1]. Dengan panjang gelombang ini maka cahaya inframerah tidak akan terlihat oleh mata tetapi radiasi panas yang ditimbulkannya masih dapat dirasakan/dideteksi. Pada dasarnya komponen yang menghasilkan panas juga akan menghasilkan radiasi inframerah termasuk tubuh manusia maupun tubuh binatang. Cahaya inframerah, walaupun mempunyai panjang gelombang yang sangat panjang tetap tidak akan dapat menembus bahan-bahan yang tidak dapat melewatkan cahaya yang nampak sehingga cahaya inframerah tetap mempunyai karakteristik seperti halnya cahaya yang nampak oleh mata.

Light Emitting Diode (LED) inframerah merupakan suatu LED yang menghasilkan inframerah. Cahaya inframerah pada sensor dihasilkan oleh Light Emitting Diode (LED) inframerah kemudian diteteksi oleh detektor inframerah berupa phototransistor. Pada saat sinar inframerah terpotong maka detektor mengirimkan nilai bacaan kepada mikrokontroler yang hasilnya berupa perhitungan jumlah hasil produksi sepatu. Gambar cara kerja sensor inframerah ini dapat dilihat pada Gambar 2 yang terdapat di bawah ini.

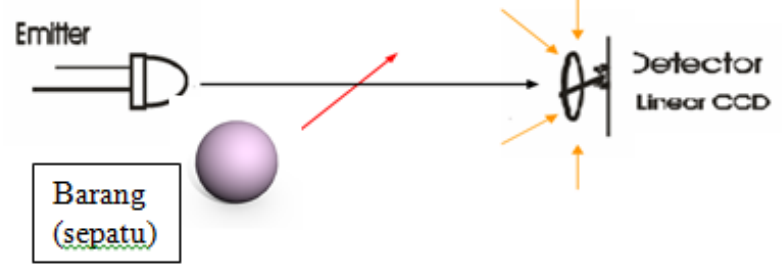

- Gambar 2. Cara Kerja Sensor Inframerah

Detektor inframerah adalah komponen yang digunakan untuk mendeteksi sinyal cahaya yang dihasilakan dari LED inframerah dan mengubahnya menjadi isyarat listrik yang berisi isyarat informasi yang dikirimkan. Arus listrik tersebut kemudian diperkuat untuk selanjutnya diolah sehingga dapat dikeluarkan pada rangkaian elektronika.

\section{IC REGULATOR LM7805}

Komponen IC voltage regulator merupakan sebuah komponen yang berfungsi untuk menurunkan tegangan DC dari tegangan yang lebih tinggi menjadi tegangan yang lebih rendah dan stabil yang sesuai dengan spesifikasi dari IC yang digunakan. Tegangan input yang dibutuhkan oleh mikrokontroler dan komponen lainnya pada perancangan alat ini adalah sebesar 5 Volt. Pada perancangan ini akan digunakan IC voltage regulator LM7805 karena menghasilkan tegangan output sebesar 5 volt DC dikarenakan modul-modul pada perancangan alat ini bekerja dengan tegangan $+5 \mathrm{~V}_{\mathrm{DC}}$. Kaki pin IC tersebut adalah pin tegangan masukan $(I N)$, pin ground $(G N D)$, dan pin tegangan keluaran $(O U T)$.

\section{PHOTOTRANSISTOR}

Komponen elektronik yang dapat digunakan untuk menangkap pancaran sinar dari LED infrared adalah phototransistor. Phototransistor merupakan jenis transistor yang biasa basisnya berupa sinar infrared. Phototransistor ini digunakan karena phototransistor sangat peka dan sensitif terhadap cahaya, sehingga sangat baik digunakan untuk merespon sinar yang dipancarkan oleh LED infrared. Phototransistor ini akan diletakkan di setiap line produksi, berhadapan dengan LED infrared yang berfungsi mendeteksi ada atau tidaknya barang yang lewat.

\section{BUZZER}

Buzzer pada perancangan alat penghitung jumlah hasil produksi ini digunakan untuk menghasilkan bunyi bila tingkat persentase kegagalan hasil produksi lebih dari yang telah ditentukan. Alasan utama dipilihnya komponen buzzer karena bekerja sesuai dengan tegangan yang dirancang yaitu $+5 \mathrm{~V}_{\mathrm{DC}}$ serta ukuran buzzer yang kecil, fungsinya yang sesuai dengan perancangan alat ini dan harga yang ekonomis merupakan nilai tambah dalam pemilihan komponen ini.

\section{TRANSCEIVER ASK $433 \mathrm{MHz}$}

Alat pemantau jumlah hasil produksi ini menggunakan modul transceiver ASK $433 \mathrm{MHz}$ sebagai sarana komunikasi antara mikrokontroler line produksi dan mikrokontroler pusat. Komunikasi secara wireless ini juga digunakan antara mikrokontroler pusat dan modul LAN. Modul transceiver ini dipilih karena mudah didapat di pasaran dan sudah menunjang komunikasi wireless yang terjadi dengan pengiriman data yang dilakukan cukup sederhana. Data yang dikirimkan berupa 1 karakter yang berarti tidak banyak data yang dikirimkan sehingga proses komunikasi dapat berjalan dengan baik. Transceiver $433 \mathrm{MHz}$ ini merupakan modul komunikasi data secara 
nirkabel dengan menggunakan teknik modulasi ASK. Modul transceiver ini bekerja pada level tegangan sebesar $5 \mathrm{~V}_{\text {DC. }}$ Pada aplikasi dalam penelitian ini, transceiver $433 \mathrm{MHz}$ ini menggunakan sumber tegangan yang sama dengan mikrokontroler yang digunakan. Transmisi data pada modul transceiver ini bersifat transparan sehingga data yang dikirim sama dengan data yang diterima. Proses pengiriman dan penerimaan data terintegrasi secara half duplex berdasarkan dari spesifikasi yang ada. Modul ini juga memiliki konsumsi daya yang rendah sehingga dapat menghemat daya.

\section{JARINGAN LAN}

LAN (Local Area Network) merupakan rancangan dasar jaringan komputer. LAN adalah jaringan yang dibatasi oleh area yang relative kecil, umumnya dibatasi oleh area lingkungan seperti sebuah perkantoran di sebuah gedung, atau sebuah sekolah, dan biasanya tidak jauh dari sekitar $1 \mathrm{~km}$ persegi. Secara tipikal, LAN dapat berupa dua buah komputer atau lebih yang saling dihubungkan satu sama lain melalui sebuah media (kabel jaringan, komunikasi wireless, dan lain-lain) sehingga setiap node komputer dapat saling melakukan akses. LAN tidak selalu berupa komputer-komputer yang dihubungkan, tetapi juga terdiri atas sekumpulan perangkat komunikasi seperti komputer-komputer server dan client, hub, bridge, repeater, printer dan lain-lain.

Sebuah LAN dibatasi oleh lokasi secara fisik, oleh karena itu penggunaan LAN itu sendiri mengakibatkan semua komputer yang terhubung dalam jaringan dapat bertukar data [2]. Kerjasama ini semakin berkembang dari hanya pertukaran data hingga penggunaan peralatan secara bersama. LAN yang umumnya menggunakan hub, akan mengikuti prinsip kerja hub itu sendiri. $H u b$ tidak memiliki pengetahuan tentang alamat tujuan sehingga penyampaian data secara broadcast, dan juga karena hub hanya memiliki satu domain collision sehingga bila salah satu port sibuk maka port-port yang lain harus menunggu. Beberapa komponen dasar yang biasanya membentuk suatu LAN adalah workstation, server, link (hubungan).

\section{AMPLITUDE SHIFT KEYING}

Amplitude Shift Keying (ASK) atau pengiriman sinyal digital dengan berdasarkan pergeseran amplitudo merupakan modulasi dengan mengubah-ubah amplitude [3]. Kemunculan frekuensi gelombang pembawa tergantung pada ada atau tidak adanya sinyal informasi digital pada proses modulasi ini. Keuntungan yang diperoleh dari metode ini adalah bit per-baud (kecepatan digital) yang lebih besar. Sedangkan kesulitannya adalah dalam menentukan level acuan yang dimilikinya, yakni setiap sinyal yang diteruskan melalui saluran transmisi jarak jauh selalu dipengaruhi oleh redaman dan distorsi lainnya. Hal ini menyebabkan metode ASK hanya menguntungkan bila dipakai untuk hubungan jarak dekat saja. Faktor noise atau gangguan lain juga harus diperhitungkan dengan teliti, seperti juga pada sistem modulasi AM. Pada saat sinyal informasi digital berupa bit 0 maka hasil modulasi amplitudonya berupa tegangan nol, sedangkan ketika sinyal informasi digital berupa bit 1 maka hasil modulasi amplitudonya sama dengan tegangan carriernya. Pada dasarnya modulasi pada metode ASK dilakukan dengan melakukan switching carrier on dan off, oleh karena itu biasa dikenal dengan On-Off Keying (OOK).

Modulasi ASK mengakibatkan amplitudo carrier tersaklar $O N$ dan $O F F$ sesuai dengan kecepatan sinyal pemodulasi. Sinyal direpresentasikan dalam dua kondisi perubahan amplitudo gelombang pembawa, yaitu logika "1" dan " 0 ". Logika "1" direpresentasikan dengan status " $O N$ " (ada gelombang pembawa) sedangkan logika "0" direpresentasikan dengan status "OFF" (tidak ada gelombang pembawa). Dari dua kondisi tersebut, maka didapatkan sebuah sinyal yang termodulasi ASK. Sinyal yang telah dikirimkan akan segera diterima oleh bagian penerima (receiver) maka selanjutnya dilakukan proses demodulasi untuk mendapatkan kembali sinyal informasi yang telah dikirim. Proses demodulasi dapat dilakukan dengan dua cara yaitu coherent dan incoherent. Demodulasi coherent adalah demodulasi yang memiliki timing (fasa) yang sama dengan sinyal carrier yang datang, teknik ini dilakukan dengan cara antara gelombang ASK yang datang dengan osilator lokal yang di-match-kan dengan frekuensi carrier. Pada perancangan ini dipilih penerima ASK yang menggunakan demodulasi coherent yang juga merupakan pasangan dari pemancar yang digunakan.

\section{PENGUJIAN DAN ANALISIS}

Pengujian dan analis modul hardware pada rancangan alat pemantau hasil produksi ini adalah modul catu daya, modul mikrokontroler, modul sensor inframerah, dan modul buzzer. Pengujian terakhir yang dilakukan yaitu dengan melakukan pengujian alat secara keseluruhan. Peralatan yang digunakan untuk mendukung pengujian modul-modul tersebut adalah multimeter digital, project board, laptop, downloader atmel.

Pengujian modul catu tegangan dilakukan dengan tujuan untuk mengetahui apakah tegangan keluaran dari modul catu tegangan sudah sesuai dengan spesifikasi rancangan yang dibutuhkan atau tidak. Pengujian modul catu tegangan ini juga bertujuan untuk mengetahui apakah tegangan keluaran dari modul catu tegangan yang dirancang stabil atau tidak. Modul catu tegangan yang digunakan pada line produksi merupakan modul catu tegangan dengan sumber tegangan PLN, sedangkan modul catu tegangan yang digunakan pada modul LAN memiliki sumber tegangan PLN yang akan terhubung dengan adaptor 12V. Pengujian modul catu tegangan ini akan dilakukan dengan dua cara yaitu pengujian dengan menggunakan beban dan pengujian tanpa beban. Pengujian modul catu 
tegangan tanpa beban adalah pengujian yang dilakukan dengan cara mengukur langsung tegangan keluaran dari modul catu tegangan. Pengukuran modul catu tegangan tanpa beban yang diukur dengan multimeter digital menghasilkan tegangan keluaran sebesar 5V. Pengujian modul catu tegangan dengan menggunakan beban juga akan dilakukan dalam pengujian ini.

Hasil pengujian modul catu tegangan ini menunjukkan adanya sedikit perbedaan antara tegangan yang diukur dengan tegangan yang diinginkan. Perbedaan yang timbul dalam pengukuran ini tidak terlalu jauh berbeda sehingga masih dalam kriteria yang diinginkan. Perbedaan pengukuran ini disebabkan oleh faktor toleransi dari komponen yang digunakan dalam pengukuran modul catu tegangan ini. Dari hasil pengukuran yang didapat maka dapat disimpulkan bahwa modul catu tegangan ini dapat bekerja dengan baik dan cukup stabil sehingga modul catu tegangan ini dapat digunakan untuk alat pemantau jumlah hasil produksi dalam industri sepatu yang dirancang pada penelitian ini.

Pengujian modul mikrokontroler bertujuan untuk melihat apakah komponen mikrokontroler yang digunakan sudah berfungsi dengan baik atau belum. Pengujian modul mikrokontroler ini juga berguna untuk memeriksa port-port I/O dari mikrokontroler yang digunakan bisa berfungsi dengan baik atau tidak. Pengujian modul mikrokontroler ini akan dilakukan dengan cara memasukkan program sederhana ke dalam mikrokontroler yang akan menyalakan delapan buah lampu LED secara berurutan. Berdasarkan pengujian yang dilakukan pada modul mikrokontroler ini dapat disimpulkan bahwa mikrokontroler dapat bekerja dengan baik. LED yang dipasang pada output mikrokontroler dapat menyala sesuai dengan program yang dimasukkan ke dalam mikrokontroler. Pengujian modul sensor inframerah ini dilakukan dengan tujuan untuk mengetahui apakah sensor inframerah yang digunakan ini dapat membangkitkan pulsa yang kompatibel dengan modul mikrokontroler atau tidak.

Pengujian modul sensor inframerah ini terdapat dua macam keadaan pengukuran yaitu pada saat keadaan ketika sensor tidak terhalangi dan pada saat keadaan sensor terhalangi oleh barang. Tegangan keluaran sensor inframerah saat dihalangi merupakan nilai high sedangkan tegangan keluaran sensor inframerah saat tidak dihalangi merupakan nilai low. Pengujian modul buzzer dilakukan dengan tujuan untuk mengetahui apakah modul buzzer ini dapat berfungsi dengan baik atau tidak. Pengujian modul buzzer ini dilakukan dengan cara memberikan dua jenis input, yaitu input high dengan tegangan masukan $5 \mathrm{~V}$ dan input low dengan tegangan masukan $0 \mathrm{~V}$. Pengujian modul transceiver dilakukan untuk mengetahui apakah modu transceiver dapat melakukan pengiriman data dengan baik atau tidak sehingga dapat digunakan pada rancangan alat pemantau produksi ini. Pengujian modul ini dilakukan dengan menggunakan program Hyper Terminal. Pengujian modul transceiver akan dihubungkan ke komputer yang bertujuan untuk menampilkan kembali input yang diberikan oleh komputer pada aplikasi Hyper Terminal. Pengujian dilakukan dengan memasukan input yaitu "Nikolas". Program Hyper Terminal akan menampilkan sesuai dengan input yang diberikan. Berdasarkan pengujian diatas, dapat dikatakan bahwa modul transceiver $433 \mathrm{MHz}$ dapat bekerja dengan baik.

Pengujian secara keseluruhan alat pemantau jumlah hasil produksi dalam industri sepatu ini bertujuan untuk mengetahui apakah sistem pada alat yang dirancang telah bekerja sesuai dengan yang diharapkan atau tidak. Pengujian sistem pada alat yang dirancang secara keseluruhan dilakukan dengan cara menggabungkan semua modul, baik modul yang dirancang maupun modul yang tidak dirancang. Pengujian keseluruhan sistem alat ini dimulai dengan menyalakan seluruh catu daya agar sistem beroperasi. Setelah semua mdul terhubung, maka pengujian alat pemantau hasil produksi ini dapat dimulai. Perangkat lunak dari alat ini dapat dijalankan pada PC kepala produksi untuk melakukan pemantauan pada proses produksi. Pengujian dilakukan pertama dengan menjalankan perangkat lunak alat pemantau produksi ini yang tampilannya dapat dilihat pada Gambar 3.

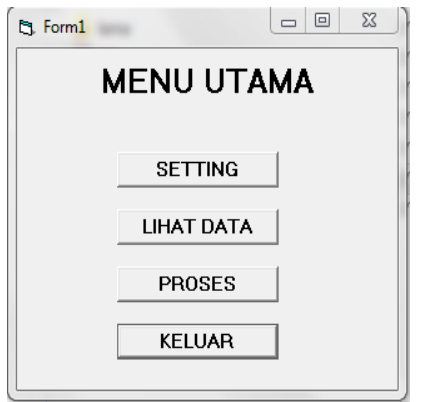

- Gambar 3. Tampilan Menu Utama

Langkah berikutnya untuk pengujian alat ini adalah dengan memasukkan jumlah target produksi yang diinginkan yang terdapat pada menu setting. Pada menu setting juga terdapat input untuk memasukkan teks berjalan yang akan muncul pada LCD monitor tempat pekerja melakukan produksi. Isi dari teks berjalan tersebut dapat diubah-ubah ketika program sedang berjalan. Tampilan untuk memasukkan jumlah target produksi yang diinginkan dan teks berjalan dapat dilihat pada Gambar 4. 


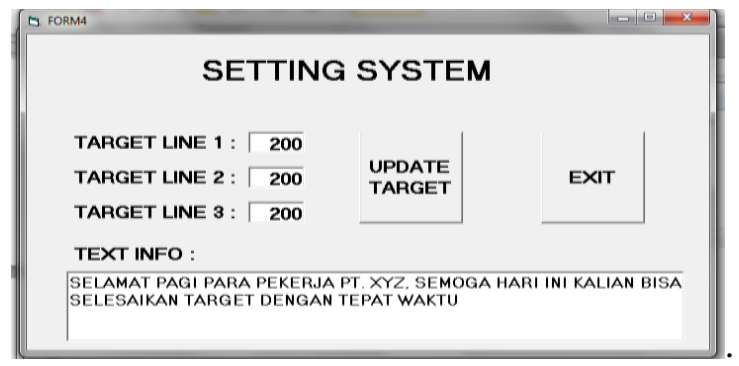

- Gambar 4. Tampilan Menu Setting untuk Mengisi Target dan Teks Berjalan

Jumlah target produksi dan teks berjalan yang telah dimasukkan akan tersimpan dengan mengklik tombol update target. Tampilan bahwa target produksi dan teks berjalan telah tersimpan dapat dilihat pada Gambar 5 .

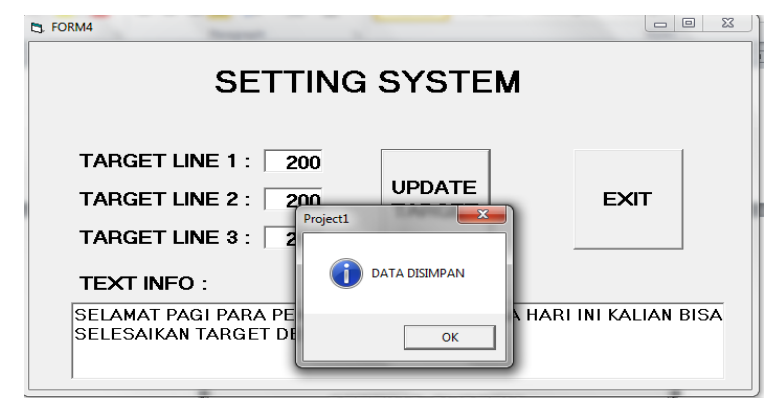

- Gambar 5. Tampilan Penyimpan Data Target Produksi dan Teks Berjalan

Pengujian selanjutnya dapat dilihat pada menu proses dimana menu ini akan memuat seluruh data-data produksi yang sedang berjalan di setiap line produksi. Menu proses ini akan dibagi menjadi dua bagian yang terdiri atas menu proses pada PC kepala produksi dan tampilan menu proses yang muncul di LCD monitor tempat pekerja. Pada menu proses ini akan terlihat data-data yang muncul yaitu target setiap line produksi, jumlah sepatu yang sukses, jumlah sepatu yang gagal, persentase kesuksesan, persentase kegagalan, sisa produksi. Pada menu proses di PC kepala produksi terdapat perbedaan dengan tampilan menu proses di LCD monitor. Perbedaannya yang dimaksud adalah adanya tombol "save shift" untuk menyimpan data per shift dan tidak adanya teks berjalan pada PC kepala produksi.

Menu proses ini akan memperoleh data hasil produksi melalui sensor inframerah yang terpasang pada setiap line produksi. Data sepatu yang berhasil dan yang gagal akan didapat ketika sepatu tersebut terdeteksi melewati pancaran sinar inframerah baik sepatu itu dinyatakan berhasil maupun gagal oleh pekerja yang ada di setiap line produksi. Data produksi yang didapat oleh sensor akan disimpan oleh mikrokontroler yang terdapat pada setiap line produksi. Data ini kemudian akan diteruskan ke mikrokontroler pusat yang berfungsi sebagai repeater secara wireless dari setiap mikrokontroler di line produksi yang ada. Mikrokontroler pusat yang bertindak sebagai repeater ini akan meneruskan data produksi yang tersimpan di dalamnya ke modul LAN secara wireless juga.

Modul LAN ini terhubung langsung dengan PC kepala produksi, sehingga data produksi dapat langsung muncul di PC kepala produksi dan LCD monitor tempat pekerja melakukan produksi sepatu. Tampilan menu proses di PC kepala produksi pada saat berlangsungnya produksi dapat dilihat pada Gambar 6 dan tampilan menu proses di LCD monitor tempat pekerja bekerja dapat dilihat pada Gambar 7.

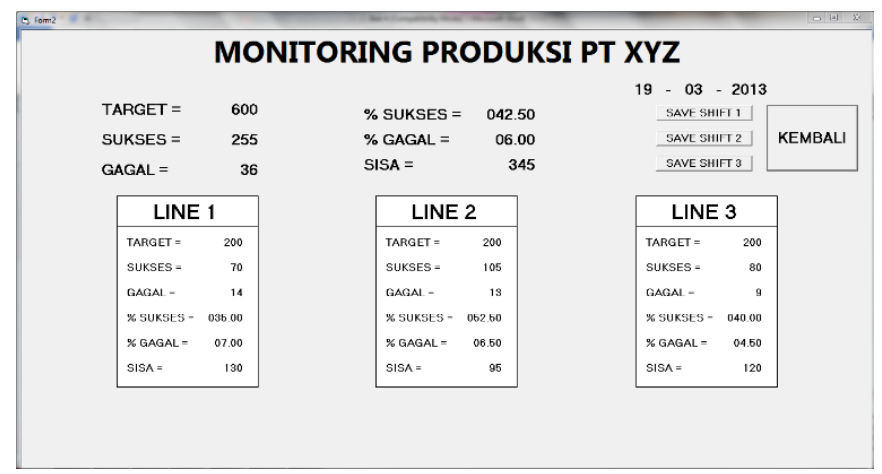

- Gambar 6. Tampilan Menu Proses di PC Kepala Produksi Saat Produksi Berlangsung 


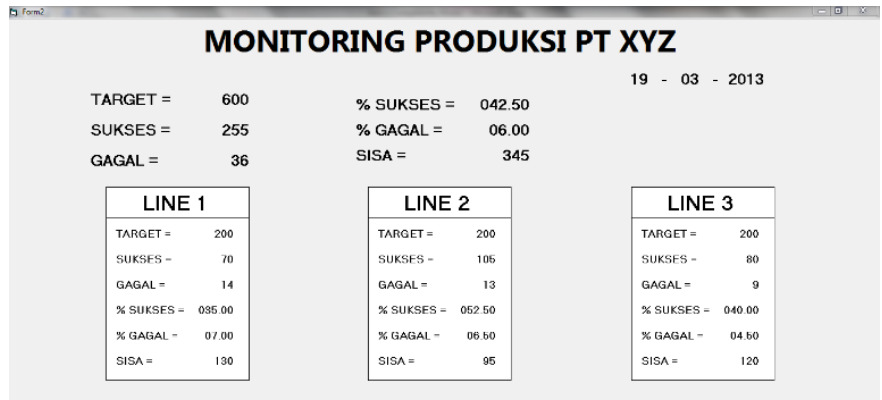

\section{--SELAMAT PAGI PARA PEKERJA PT. XYZ, SE}

- Gambar 7. Tampilan Menu Proses di LCD Monitor Saat Produksi Berlangsung

Pengujian selanjutnya adalah ketika terdapat line produksi yang bermasalah yaitu pada saat tingkat kegagalan dari setiap line produksi lebih dari 10\%. Keadaan ini akan menimbulkan suatu warning atau peringatan pada PC kepala produksi maupun pada LCD monitor tempat pekerja bekerja dengan timbulnya warna merah pada line produksi yang bermasalah.

Peringatan lain pun akan terjadi pada line produksi yang bermasalah yaitu dengan timbulnya bunyi yang dikeluarkan oleh komponen buzzer yang terpasang pada setiap line produksi. Keadaan ini harus segera ditangani oleh kepala produksi dengan cara memantau langsung ke line produksi yang bermasalah. Bunyi dari buzzer pun dapat dimatikan dengan menggunakan switch yang terpasang pada rangkaian modul buzzer. Tampilan pada saat terdapat line produksi yang bermasalah dapat dilihat pada Gambar 8 untuk di PC kepala produksi.

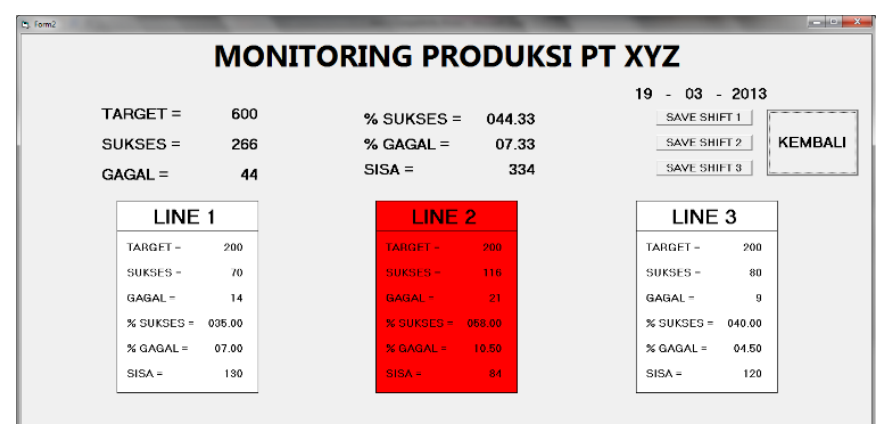

-Gambar 8. Tampilan PC Kepala Produksi Saat Line Produksi Mengalami Tingkat Kegagalan Lebih dari $10 \%$

Gambar 9 merupakan tampilan LCD monitor tempat pekerja saat line produksi mengalami tingkat kegagalan lebih dari $10 \%$.

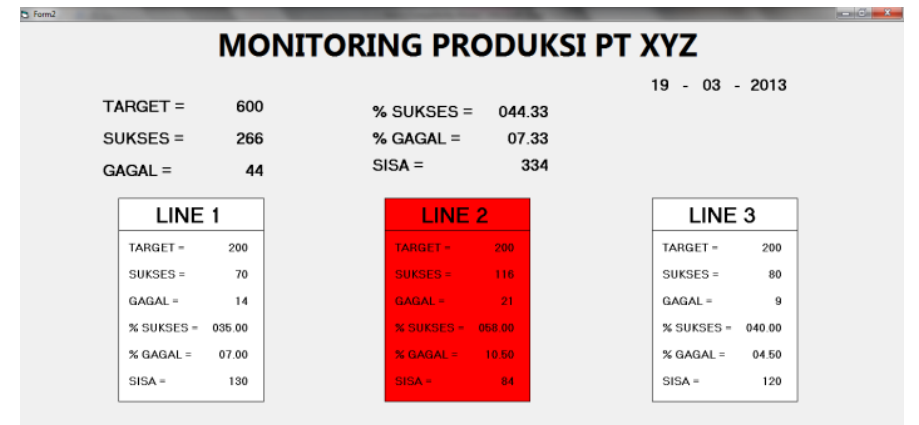

\section{IRGET DENGAN TEPAT WAKTU-- --SELAMAT}

-Gambar 9. Tampilan LCD Monitor Tempat Pekerja Saat Line Produksi Mengalami Tingkat Kegagalan Lebih dari $10 \%$

Pengujian selanjutnya adalah pengujian pada sebuah fitur laporan yang terdapat dalam rancangan perangkat lunak alat pemantau hasil produksi ini. Fitur ini dapat dilihat pada menu lihat data yang terdapat pada menu utama. Fitur laporan produksi dari alat ini berguna untuk menyimpan data-data produksi yang telah dilakukan. Laporan data produksi ini bisa dilihat kapan saja dengan frekuensi waktu per shift, per hari, per bulan dan per tahun.

Penyimpan data per shift pada saat produksi sedang berlangsung dapat dilakukan dengan menekan tombol "save shift 1 , save shift 2 , save shift 3 ". Setelah tombol save shift 1 diklik maka program perangkat lunak ini akan me-reset program ke keadaan jumlah target awal yang ditentukan. Tampilan menu lihat data hanya dapat dilihat 
pada PC kepala produksi. Gambar 10. akan menampilkan tampilan menu lihat data yang berisi laporan dari datadata produksi.

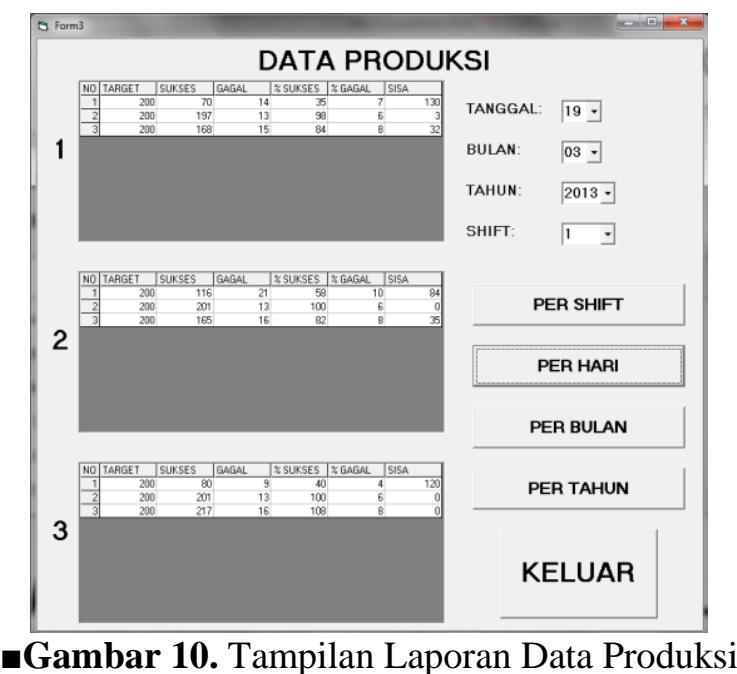

Pengujian selanjutnya adalah pengujian fitur online dengan menggunakan jaringan internet apakah alat ini bisa menampilkan data-data produksi secara online atau tidak. Pengujian untuk menentukan persentase yang diperoleh akan menggunakan sebuah persamaan yaitu jumlah produksi yang sukses maupun gagal dibagi dengan target produksi setiap line produksi kemudian dikalikan dengan 100\% sehingga diperoleh persentase hasil produksi. Pengujian fitur online ini akan menggunakan sebuah tablet PC berupa Ipad dan menggunakan sebuah software bernama "iTeleport" yang terdapat pada PC kepala produksi dan Ipad. Software "Iteleport" ini akan menampilkan tampilan layar pada PC kepala produksi dan juga akan menampilkan tampilan layar pada LCD monitor. Fitur ini sangat berguna ketika pemilik perusahaan sedang berada di luar kota maupun di luar negeri sehingga tetap bisa memantau dalam jarak yang jauh sekalipun. Tampilan awal software "Iteleport" pada PC dapat dilihat pada Gambar 11.

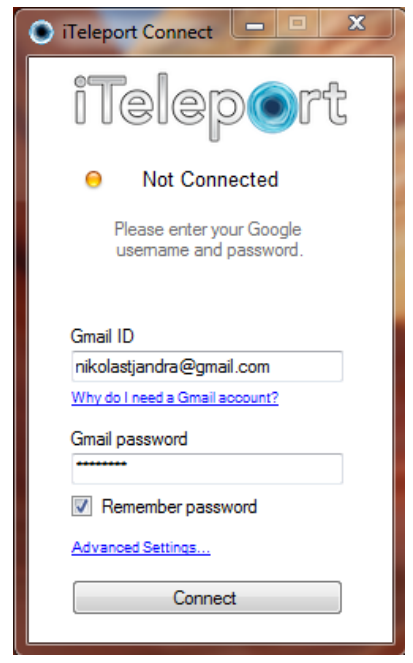

-Gambar 11. Tampilan Awal Software "Iteleport"

Software "Iteleport" pada PC akan meminta pengguna untuk memasukkan Gmail ID dan password Gmail $I D$, lalu klik tombol connect dan software ini akan langsung bisa digunakan secara online. Hal yang samapun dilakukan pada Ipad agar PC dan Ipad dapat saling terkoneksi sehingga Ipad dapat menampilkan tampilan layar PC kepala produksi dan LCD monitor tempat pekerja. Tampilan layar PC kepala produksi pada software "Iteleport"dapat dilihat pada Gambar 12. 


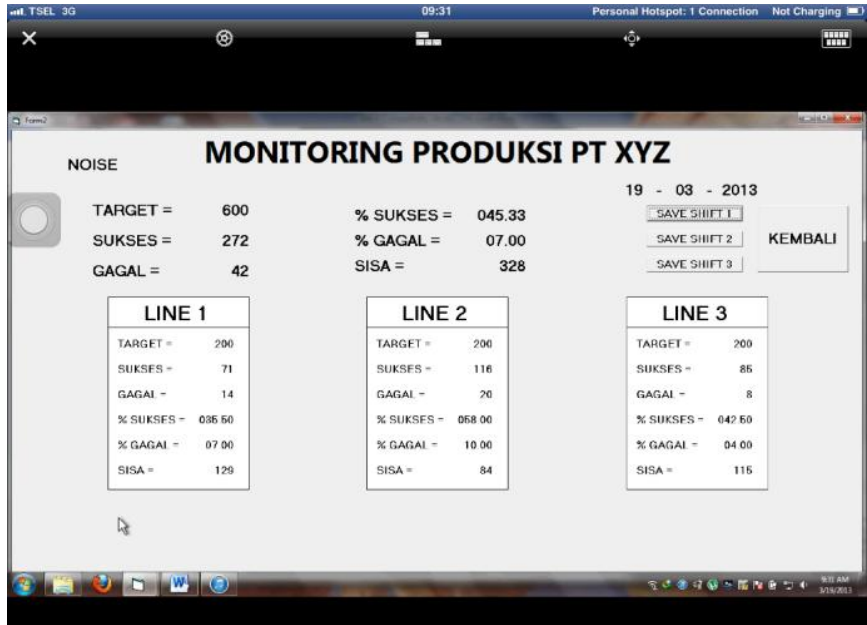

-Gambar 12. Tampilan Layar PC Kepala Produksi pada Software "Iteleport"

Tampilan LCD monitor tempat pekerja pada software "Iteleport" dapat dilihat pada Gambar 13. di halaman selanjutnya. Berdasarkan dari pengujian keseluruhan sistem yang dilakukan bahwa alat pemantau hasil produksi dalam industri sepatu dapat bekerja dengan baik dan lancar sesuai yang diharapkan.

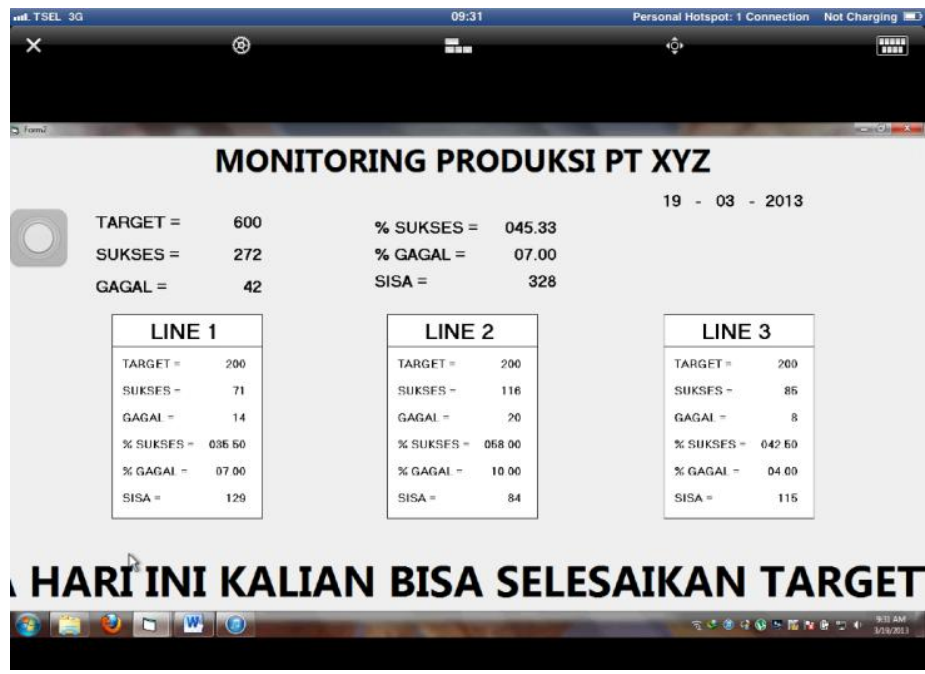

-Gambar 4.13 Tampilan LCD Monitor Tempat Pekerja pada Software "Iteleport"

\section{KESIMPULAN}

Berdasarkan atas hasil pengujian yang dilakukan pada alat pemantau hasil produksi ini dapat ditarik beberapa kesimpulan. Modul wireless dengan menggunakan transceiver $433 \mathrm{MHz}$ dapat bekerja dengan cukup baik dalam proses pengiriman data dari mikrokontroler sampai PC sehingga dapat langsung ter-update data jumlah produksi sepatu pada PC. Pada LCD monitor di tempat pekerja industri, LCD monitor akan melakukan refresh setiap 1 detik untuk menampilkan data seperti yang ada pada tampilan PC kepala produksi agar proses aliran data dapat berjalan dengan baik.

Data hasil produksi sepatu yang diperoleh dapat ditampilkan secara online melalui software "iTeleport" yang dapat diakses menggunakan alat elektronik seperti laptop dan tablet PC yang berbasis "Apple" maupun "Android".

\section{DAFTAR PUSTAKA}

[1] R. Anthoni, Infrared Detectors, Florida: Taylor and Francis Group, 2011.

[2] S. A. David, Local Area Network, 3rd ed, New Jersey: Prentice Hall, 2001.

[3] L. W. Couch II, Digital and Analog Communication Systems, 7th ed, New Jersey: Pearson Prentice Hall, 2007 